Research

\title{
Preliminary Study: Detection of Ecto and Endoparasites Among Wild Rats From Urban Area in Blimbing, Malang, East Java
}

\author{
Shelly Kusumarini R', Reza Yesica', Ida Bagus Gde Rama Wisesa', Jenny Hermanto², \\ Yustia Nurholizah', Maria Widyaneni Trinastuti ${ }^{2}$ \\ 'Department of Parasitology, Faculty of Veterinary Medicine, Universitas Brawijaya \\ ${ }^{2}$ Student on Faculty of Veterinary Medicine, Universitas Brawijaya \\ *Corresponding author: shellykusuma224@ub.ac.id \\ Submitted March 26, 2021 Accepted May 8, 2021
}

\begin{abstract}
Zoonotic parasitic infections is one of the global public health issues. The complex parasite transmission allows for the relationship between people, animals, vectors, and the environment. The existence of rat in the environment has an important role as a host and reservoir for various types of ecto and endoparasites. This study was conducted to collect informative data on the parasitic infection of wild rats in Blimbing sub-district, Malang city, East Java. A total number of eight wild rat were captured using live-traps from landfills during 4 days. They were classified by sex, weight and body length. The rats were anesthetized, collecting for any ectoparasites and then their carcasses were dissected for examinations of endoparasites. The result of this study show succesfull live-trap of rodents including Rattus norvegicus (87.5\%) and Suncus murinus (12.5\%). 50\% of sampled rodents were male, $37.5 \%$ were female, and $12.5 \%$ of female the musk shrew. The presence of helminthes infection in all wild rats, namely Hymenolopis nana, Syphacia obvelata, Nippostrongylus brasiliensis. Furthermore, the ectoparasites identification were Xenopsylla cheopis, Echinolaelap echidninus, and blood protozoa identifications Trypanosoma lewisi. Based on the results show $100 \%$ of wild rats positive infections of endo-ectoparasites. This study indicates to continuous study among rodents' parasites in wild rats in different urban areas and analysis of their potential impact on public health.
\end{abstract}

Keywords: public health, landfill, parasites, rat, zoonosis

\begin{abstract}
ABSTRAK
Infeksi parasit zoonosis merupakan salah satu masalah kesehatan masyarakat yang terjadi secara global. Transmisi parasit yang kompleks memungkinkan terdapat hubungan antara manusia, hewan, vektor, dan lingkungan. Keberadaan tikus di lingkungan memiliki peran penting sebagai inang dan reservoir untuk berbagai jenis ekto dan endoparasit. Penelitian ini dilakukan untuk mengumpulkan data informatif terkait infeksi parasit pada tikus liar di Kecamatan Blimbing, Kota Malang, Jawa Timur. Sebanyak delapan tikus liar ditangkap menggunakan perangkap dari tempat pembuangan sampah selama 4 hari. Tikus dikelompokkan berdasarkan jenis kelamin, berat badan, dan panjang tubuh. Tikus tersebut dibius, diperiksa dan dikumpulkan ektoparasitnya dan kemudian dibedah untuk pemeriksaan endoparasit. Hasil penelitian ini menunjukkan jenis tikus yang tertangkap adalah Rattus norvegicus (87,5\%) dan Suncus murinus (12,5\%). Sebanyak 50\% adalah tikus jantan, $37,5 \%$ tikus betina, dan $12,5 \%$ adalah betina dari Suncus murinus. Ditemukan adanya infeksi cacing pada semua tikus yaitu Hymenolopis nana, Syphacia obvelata, Nippostrongylus brasiliensis. Selanjutnya, ektoparasit yang ditemukan diantaranya Xenopsylla cheopis, Echinolaelap echidninus, dan protozoa darah Trypanosoma lewisi. Berdasarkan hasil penelitian ini menunjukkan bahwa 100\% tikus liar positif infeksi endo-ektoparasit. Penelitian ini mengindikasikan perlunya studi lebih lanjut mengenai keberadaan parasit pada tikus liar di wilayah perkotaan dan menganalisis potensi bahayanya terhadap kesehatan masyarakat.
\end{abstract}

Kata kunci: kesehatan masyarakat, TPA, parasit, tikus, zoonosis 


\section{INTRODUCTION}

Zoonotic parasitic infections are one of the global public health issues. Now, a major concern is the potential of zoonotic disease connecting with wild rodents to spread of most emerging infectious disease. In fact, Urban ecosystems present various species of rodents (e.g., Rattus norvegicus, Rattus r. diardii, and Rattus norvegicus (Dina \& Ustiawan, 2013; Paramasvaran et al., 2009). The existence of wild rodents in the environment has an important role as hosts of ectoparasites as well as reservoirs for various types of viruses, bacteria, rickettsia, and endoparasites such as protozoa, and helminths (Moravvej et al., 2015; Tijjani et al., 2020a).

The Complex parasite transmission allows for the relationship between people, animals, vectors, and the environment. Until now, increasing cases related parasitic zoonosis were reported around the world (WHO, 2019). This condition associated with the ecological system formed dynamically between rodent reservoirs populations and humans causing a risk of rodent-borne zoonoses transmission (Gholipoury et al., 2016).

Scientific literature associated to rodent-borne parasites in Indonesia insists on the role of rodents as biological vector of ectoparasites (e.g., Xenopsylla cheopis, Hoplopleura pacifia, Poliplax spinulosa, and Ornithonyssus bacoti), zoonotic endoparasites by helminths (e.g., Capillaria hepatica, Gongylonema neoplasticum, Hymenolepis diminuta, Hymenolepis nana, and Syphacia muris) and blood protozoa particularly Trypanosomiasis and Leishmaniasis (Afililla et al., 2017; Ernawati \& Priyanto, 2013; Musyaffa et al., 2020; Sari et al., 2020).

Rodent not only spread infectious diseases but also made economic, and social problems. Nowadays, research in rat needs, as a first concern, to identifying most reservoirs of rodentborne zoonoses and mapping potential regions that occur of transmission, and minimizing transmission risk in humans (Han et al., 2015). Considering the distribution of Rodent-borne zoonoses throughout Indonesia especially in urban area like Malang city, East Java. Preliminary study needed to provide local data at the landfill in Blimbing sub-district, Malang city. Based on information from the local community, in this area, there were wild rats that existed. The study aims to undertake the diversity of rodents parasites as potential of zoonotic parasitic which risks that threaten health.

\section{Objective}

This study aimed to undertake the diversity of rodents parasites and collect informative data on the parasitic infection at the landfill area in Blimbing sub-district, Malang city, Indonesia.

\section{MATERIAL AND METHODS}

\section{Ethical Statement}

This study was approved by the Institutional Animal Care and Use Committee of the Brawijaya University, Malang (Ref. No: 074-KEP-UB-2020). All protocols and procedures for trapping and handling of animals in this study are accordance with the direction of the Ethics Committee, Brawijaya University.

\section{Trapping Locations and Sampling}

Trapping of rodents was conducted in the landfill area in Blimbing sub-district from 10 August to 14 August 2020. The landfill is situated (-7.9591017 S; 112.6379437 E) near Malang city, East Java. Almost local people work as scavengers and have a semi-permanent house around trapping locations. Urban rodents were trapped around local community lives. The location was closed with railroad and waterway (Figure 1). All rodents were trapped alive using a rectangular metal trap baited with fried fish, salted fish, and roasted coconut. Rodents capture were transported using a plastic bucket to the laboratory and euthanized (ketamine:xylazine) with the guidelines for the humanely, following which, age, weight and sex determined (AVMA, 2020; Tijjani et al., 2020b).

\section{Animal Identification}

Identify the rodent species by morphological measurements and physical appearances. External identification and inspection based on measurements head and body length, weight, sex and maturity determination of development stage consist of juvenile, sub-adult, and adult. It an help to correctly identify each animal to the species level based on characteristics (Herbreteau et al., 2011).

\section{Examination and Identifications of Ectoparasites}

Inspect and collection of ectoparasites from an anesthetized rat with a comb or dissecting forceps to find ectoparasites in the fur. For better examination, the body of an anesthetized rat can take 

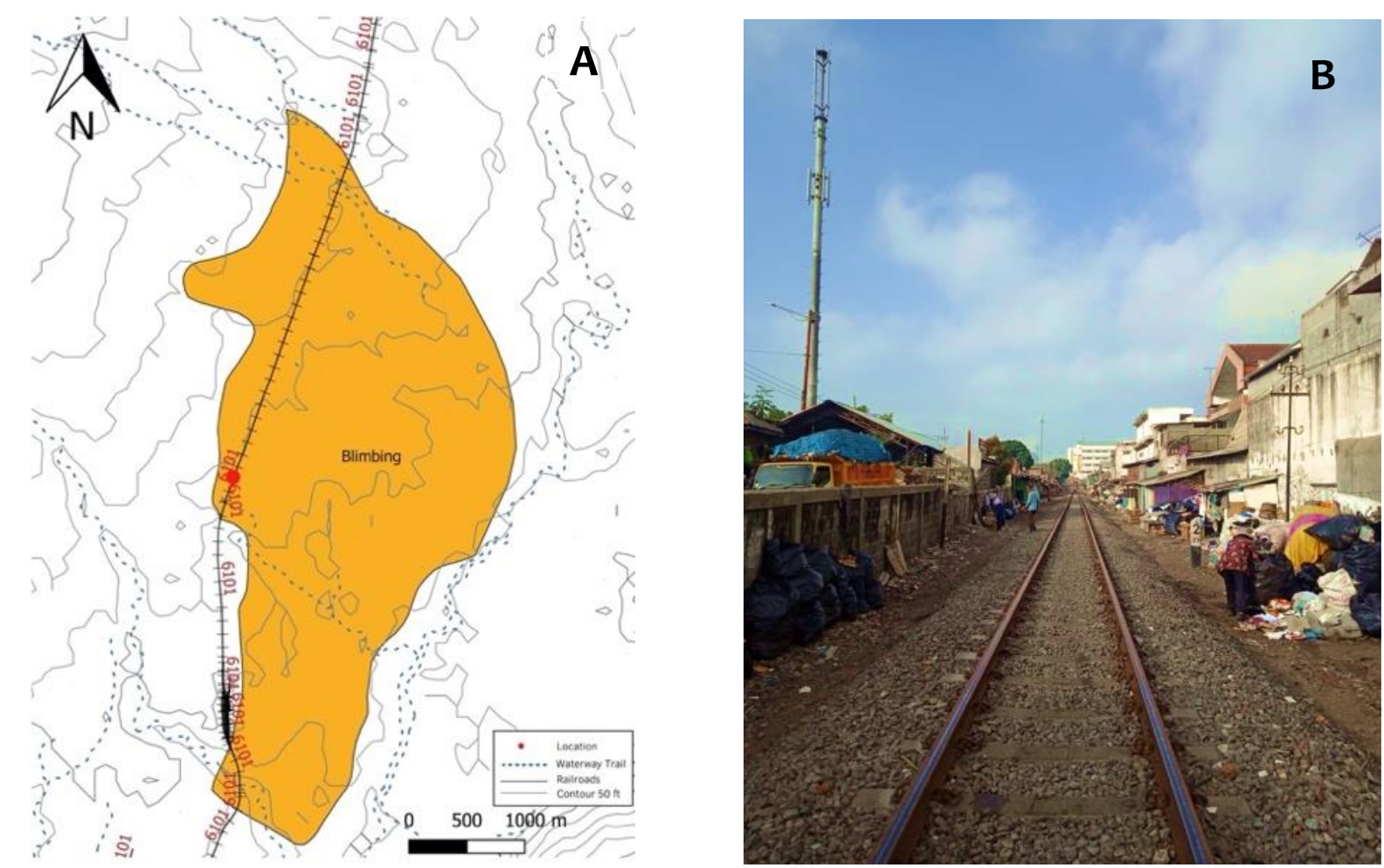

Figure 1 The study area, in Blimbing sub-district, Malang City, East Java showing the study sites circled in red (A) and the local community lives in landfills area around the railroad (B).

head and underbody, fleas, and lice usually predilection on the lower part of the abdomen, and underbody. For chigger mites usually in the ears part. Any ectoparasites were placed in a vessel tube containing $70 \%$ alcohol. Each tube was used for each rodent and labeling. After that, removed ectoparasites for processing used alcohol fixation increase concentration, clearing with xylene, and mounting on microscope slides for identification with standard protocols (Herbreteau et al., 2011; Paramasvaran et al., 2009).

\section{Examination and Identifications of Endoparasites and Blood Protozoan}

Rats were dissected following the protocol previously described (Herbreteau et al., 2011). Fecal samples from gastrointestinal tracts (GITs) were examined by wet smear after fecal flotation with saturated sodium chloride solution to detect helminth eggs, larva, cyst, and parasite's ova. Blood collection by cardiac puncture. The blood smears must be used fresh blood added with anticoagulant (EDTA). The thin and thick blood smears were stained with Giemsa. The prepared slides were viewed under microscope Olympus CX-21 (Olympus Corp., Tokyo, Japan) with suitable magnification power (100x-1000x) and captured by Opti Lab Advanced Plus camera (Miconos Corp., Yogyakarta, Indonesia) (Gholipoury et al., 2016).

After identification of parasites, the prepared slides were measured by ImageJ software to know the length total in micrometers. Data were analyzed using descriptive study.

\section{RESULTS AND DISCUSSION}

A total number of eight rodents including Rattus norvegicus (87.5\%) and Suncus murinus (12.5\%) were capture in this study. $50 \%$ of sampledf rodents were male, $37.5 \%$ were female, and $12.5 \%$ of female the musk shrew. Average weight of sample were male $128,2 \mathrm{~g}$ and $204.7 \mathrm{~g}$ were female. Parasite infestation, including endoparasites was detected $100 \%$ and ectoparasites was detected in $87.5 \%$. Total number endoparasites infection of rodents were $100 \%$, infestation of ectoparasites were $87.5 \%$ and blood protozoa were $37.5 \%$ (Table 1 ). 
Three species of endoparasites (Helminths) were found in fecal samples from gastrointestinal tracts (GITs) of wild rat and the musk shrew (Table 2). They were classified as Cestodes (one species) and Nematoda (two species). Every species was identification from wet smear after fecal flotation and examine based on egg morphology (Baker, 2007). After examined, all of them (Hymenolopis nana, Syphacia obvelata, and Nippostrongylus brasiliensis) have been categories as zoonotic parasites (Figure 2). The protozoans were observed using microscopic examination and in this study found Trypanosoma lewisi infection of three wild rat (Figure 2). Two species of ectoparasites (flea and mite) were infestation in the fur. One species of fleas (Siphonaptera), Xenopsylla cheopis, on the lower part of the abdomen, and the ventral body. The mites, Echinolaelap echidninus, found on the femur (Table 2). In most cases, many species of fleas especially Xenopsylla cheopis are biological vector of trypanosomes (Figure 2).
Most parasite infestation of wild rat was detected near semi-permanent house in Landfill area. Syphacia obvelata also called pinworm was collcted primarily in the the musk shrew. Additionally, the recorded data showed high infections of Hymenolopis nana in all wild rat.

Rodents play a a major role in transmission of a large number of infectious diseases to human. Immediately, Rodent-borne disease have multiple effects on public health (Meerburg et al., 2009). We capture eight small mammals that included of rodents and shrews. A total number of seven wild rat (Rattus norvegicus) identifications from urban area and one species of the musk shrew.

Almost wildrats infected of ectoparasites, and endoparasites, this is indicated that the urban habitat such as Blimbing sub-district has a potential relationship with infestation of parasites. The host (Rattus norvegicus) and the musk shrew (Suncus murinus) of the majority of the endoparasites related with medical importance. Most wild rats with

Table 1 Identification of rodent species and parasites infestation in Blimbing sub-district

\begin{tabular}{|c|c|c|c|c|c|c|c|c|}
\hline \multirow{2}{*}{ Family } & \multirow{2}{*}{ Species } & \multicolumn{2}{|c|}{ Sex } & \multicolumn{2}{|c|}{ Age } & \multicolumn{3}{|c|}{ Parasite } \\
\hline & & Female & Male & Juveniles & Adult & Ecto & Endo & Blood \\
\hline Muridae & Rattus norvegicus & $3(37.5 \%)$ & $4(50 \%)$ & $1(12.5 \%)$ & $6(75 \%)$ & $7(87.5 \%)$ & $7(87.5 \%)$ & $3(37.5 \%)$ \\
\hline Soricidae & Suncus murinus & $1(12.5 \%)$ & 0 & $1(12.5 \%)$ & 0 & 0 & $1(12.5 \%)$ & 0 \\
\hline & Total & $50 \%$ & $50 \%$ & $25 \%$ & $75 \%$ & $87.5 \%$ & $100 \%$ & $37.5 \%$ \\
\hline
\end{tabular}

Table 2 Percentage of parasites infestation in Blimbing sub-district

\begin{tabular}{|c|c|c|c|c|}
\hline Parasite & Species & Characteristic & Host & $\begin{array}{c}\text { Present of Infested } \\
\text { samples (\%) }\end{array}$ \\
\hline \multirow[t]{6}{*}{ Endoparasites } & Cestodes & & $R n$ & $87.5(n=7)$ \\
\hline & Hymenolopis nana & Dwarf Tapeworm & Sm & $12.5(n=1)$ \\
\hline & Nematoda & & & \\
\hline & Syphacia obvelata & Pinworm & Sm & $12.5(n=1)$ \\
\hline & Nippostrongylus brasiliensis & Hookworm & $R n$ & $87.5(n=7)$ \\
\hline & & & Sm & $12.5(n=1)$ \\
\hline \multirow[t]{2}{*}{ Ectoparasites } & Xenopsylla cheopis & Rat flea & $R n$ & $50(n=4)$ \\
\hline & Echinolaelap echidninus & Rat mite & $R n$ & $62.5(n=5)$ \\
\hline Blood protozoa & Trypanosoma lewisi & Hemoflagellates & $R n$ & $37.5(n=3)$ \\
\hline
\end{tabular}

Note: $\mathrm{n}=$ Total number of rodent infestations; $\mathrm{R} n=$ Rattus norvegicus; $\mathrm{Sm}=$ Suncus murinus 


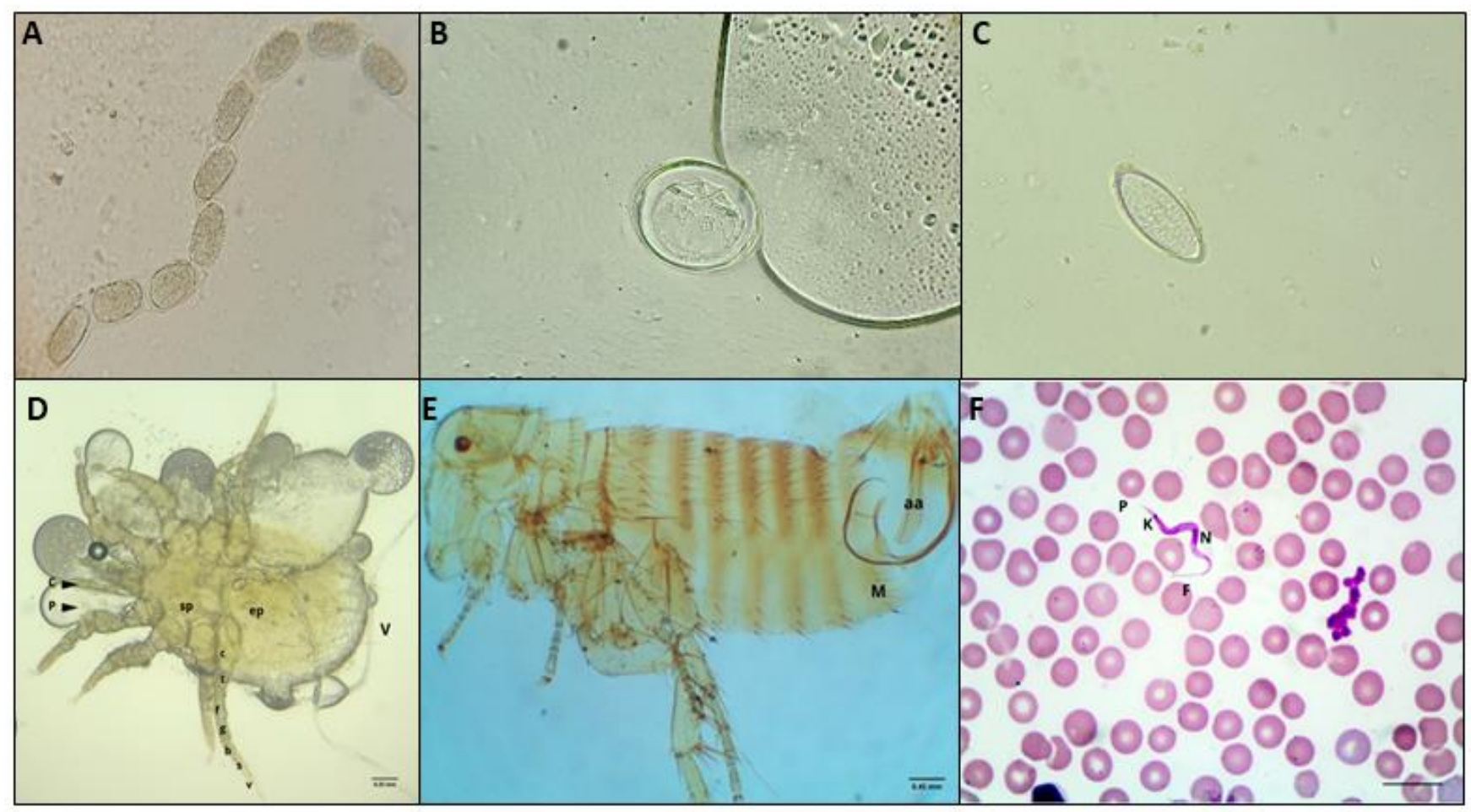

Figure 2 Nippostrongylus brasiliensis (A); Hymenolopis nana (B); Syphacia obvelata (C) identification from gastrointestinal tracts (GITs) with magnification 40x; Echinolaelap echidninus (D) ventral side showing chelicera $(C)$, palpus (P), sternal plate (sp), epigynial plate (ep), leg segments [coxa (c), trochanter (t), femur (f), genu (g), tibia (b), tarsus (s) and pulvillus (v)]; Xenopsylla cheopis (E) showing Aedeagal apodeme of male (aa); Trypanosoma lewisi in the blood showing posterior margin( $\mathrm{P})$, kinetoplast (K), nucleus ( $N)$, flagella (F). Scale-bar: $5 \mu \mathrm{m}$.

infection of endoparasites closely found in areas with human activities. Every day, local community in this study area would be seen a wild rat wandering around the landfill and sewer. Present study reported that urban area and market town can being a habitat for rodents and shrew (e.g., Rattus r.diardii, Rattus tanezumi, Rattus norvegicus, and Suncus murinus (Dina \& Ustiawan, 2013; Mohd Zain et al., 2012; Paramasvaran et al., 2009).

Rodents are well-known reservoirs and host for number of infectious diseases. In this study, found endoparasites from GITs included Nippostrongylus brasiliensis, Hymenolopis nana, Syphacia obvelata (Figure 2). Recent study in Surabaya city, one of capital city in Indonesia located near Malang city reported that prevalence of Hymenolepis nana in 42\% (Prasetyo, 2016). This parasites as well-known of zoonotic agent in human lived in intestines, also called hymenolepiasis caused by Hymenolepis diminuta, and Hymenolepis nana. Infections of dwarf tapeworm have been seen more often among children (Anorital, 2014; Prasetyo, 2016). In this study, oxyurids (Syphacia muris) from shrew are found in the caecum. In nematodes, the dominant preferences for Syphacia muris commonly infect rodents (e.g., laboratory rats, wild rats, and mice) (Khalil et al., 2014; Priyanto \& Ningsih, 2014). Nippostrongylus brasiliensis is a trichostrongylid nematode in superfamily Trichosngyloidea commonly found in small intestine. Pathological effect of the infections cause inflammation in the skin, lungs, and intestine (Baker, 2007). Previous study reported the prevalence of Nippostrongylus brasiliensis is $85.7 \%$ with parasites indexes $2-118$ individual parasites in each host, respectively (Musyaffa et al., 2020). This is appropriate the high risk of transmission of endoparasites to humans.

In this work, total three Rattus norvegicus blood samples were infected with Trypanosoma lewisi (37.5\%) (Figure 2). The prevalence of trypanosomiasis of wild rats in Banyuwangi city, East Java was $1.67 \%$. The infection of Trypanosoma lewisi in wild rats has a potential risk to transmitted human (Afililla et al., 2017). The distribution of the blood protozoa is worldwide. In Iran higher rates of infection have been reported in Trypanosoma lewisi in $11.54 \%$ (Seifollahi et al., 2016). In the current study, 
wild rat species could be potential as reservoirs of blood protozoa. This situation arises from the recent changes in the global climate, ecosystem composition, and natural environment which led to the spread and transmission of Trypanosoma lewisi by rodents.

The results of this study on Blimbing sub-district showed different species of ectoparasites comprising two order namely Mesostigmata (mites) and Siphonaptera (fleas) were collected from rats from urban area (Table 2). A total number of seven wild rat from landfill area were the predominant ectoparasites found on the surface body of Rattus norvegicus was Echinolaelap echidninus followed by fleas Xenopsylla cheopis. Mites, Echinolaelap echidninus occurs throughout the worldwide as a parasite of brown rat, Rattus norvegicus and other rodents (Montasser, 2006). The most rodents were found to be infested with at least one species of ectoparasites. In this study, no ticks were found on urban rats sampled, which is close with previous study in Malaysia (Paramasvaran et al., 2009). Xenopsylla cheopis is also an intermediate host of helminths (e.g., Hymenolepis diminuta and Hymenolepis nana) and this oriental rat flea is main factor of Yersinia pestis, the major cause of bulbonic plague in human. Also, the ectoparasites is only parasites can transmitted of murine typhus by faeces (Taylor et al., 2007).

This is the first report on endoparasites, ectoparasites and blood protozoa of wild rat and the the musk shrew in landfills area, Blimbing subdistrict, Malang City, East Java. The uncover study findings that wild rats captured in this area were infected with various species of parasites of zoonotic importance and the musk shrew was infected with Syphacia obvelata was known zoonotic. The preliminary study founded a potensial risk of rodent-borne zoonoses transmission to humans especially the scavenger. From this condition is strongly recommended to take another study not only in the region but also in other places in Malang city. Accordingly, control strategy is need to reduce of rodents population. Furthermore, a campaign can be carried out to create awareness of people about the risk of rodent-borne diseases.

\section{ACKNOWLEDGEMENTS}

The authors would like to thank all of staff and assistant in Veterinary Parasitology Laboratory. This study was financially supported by Faculty of Veterinary
Medicine, Brawijaya University, Malang. The authors declare that there is no conflict of interests.

"All authors declare that there are no conflicts of interest".

\section{REFERENCES}

Afililla Z, Suwanti LT, Sudjarwo SA, Koesdarto S, Yunus M, Plumeriastuti H. 2017. Prevalensi trypanosomiasis tikus (Rattus sp.) liar di Banyuwangi. Journal of Parasite Science 1(2): 39-42.

Anorital. 2014. Kajian penyakit kecacingan Hymenolepis nana. Jurnal Biotek Medisiana Indonesia 3(2): 37-47.

[AVMA] American Veterinary Medical Association. 2020. AVMA Guidelines for the Euthanasia of Animals (2020 ed). American Veterinary Medical Association. 60-61.

Baker DG. 2007. Flynn's Parasites of Laboratory Animals. Second Edition. Wiley-Blackwell. Oxford. 330-340

Dina S, Ustiawan A. 2013. Spesies tikus, cecurut dan pinjal yang ditemukan di pasar Kota Banjarnegara, Kabupaten Banjarnegara tahun 2013. Balaba 9(2):39-46.

Ernawati D, Priyanto D. 2013. Pola sebaran spesies tikus habitat pasar berdasarkan jenis komoditas di pasar kota Banjarnegara. Balaba. 9(02): 58-62.

Gholipoury M, Rezai HR, Namroodi S, Arab KF. 2016. Zoonotic and non-zoonotic parasites of wild rodents in Turkman Sahra, Northeastern Iran. Iranian Journal of Parasitology 11(3): 350-357.

Han BA, Schmidt JP, Bowden SE, Drake JM. 2015. Rodent reservoirs of future zoonotic diseases. Proceedings of the National Academy of Sciences of the United States of America 112(22): 7039-7044.

Herbreteau V, Jittapalapong S, Rerkamnuaychoke W, Chaval Y, Cosson JF, Morand S. 2011. Protocols for Field and Laboratory Rodent Studies. http://hal.ird.fr/ird-00714514.

Khalil Al, Lashein GH, Morsy GH, El-Mottaleb ADI. 2014. Oxyurids of wild and laboratory rodents from Egypt. Life Science Journal 11(3): 94-107.

Meerburg BG, Singleton GR, Kijlstra A. 2009. Rodentborne diseases and their risks for public health. Critical Reviews in Microbiology 35: 221-270.

Mohd ZSN, Behnke JM, Lewis JW. 2012. Helminth communities from two urban rat populations in Kuala Lumpur, Malaysia. Parasites and Vectors 5(1): 1-23. 
Montasser AA. 2006. The spiny rat mite Echinolaelaps echidninus. International Journal of Zoological Research 2(1): 1-13.

Moravvej G, Hamidi K, Nourani L, Bannazade H. 2015. Occurrence of ectoparasitic arthropods (Siphonaptera, Acarina, and Anoplura) on rodents of Khorasan Razavi Province, Northeast of Iran. Asian Pacific Journal of Tropical Disease 5(9): 716-720.

Musyaffa MF, Dewi K, Supriatna N. 2020. Nematoda parasit pada Rattus spp. dari Pulau Simeulue, Aceh. Jurnal Biologi Papua 12(1): 1-9.

Paramasvaran S, Sani, RA, Hassan L, Krishnasamy M, Jeffery J, Oothuman P, Salleh I, Lim KH, Sumarni, MG, Santhana RL. 2009. Ectoparasite fauna of rodents and shrews from four habitats in kuala lumpur and the states of Selangor and Negeri Sembilan, Malaysia and its public health significance. Tropical Biomedicine 26(3):303-311.

Prasetyo RH. 2016. Survey of house rat intestinal parasites from Surabaya District, East Java, Indonesia that can cause opportunistic infections in humans. Southeast Asian Journal of Tropical Medicine and Public Health 47(2): 194-198.

Priyanto D, Ningsih DP. 2014. Identification of endoparasites in rats of various habitats. Health Science Indones 5(1): 49-53.
Sari MD, Setyaningrum E, Rosa E, Sutyarso. 2020. Identifikasi ektoparasit pada tikus (Rattus sp.) sebagai vektor penyakit pes di areal Pelabuhan Panjang Kota Bandar Lampung. Jurnal Medika Malahayati 4(April): 120-128.

Seifollahi Z, Sarkari B, Motazedian MH, Asgari Q, Ranjbar MJ, Abdolahi Khabisi S. 2016. Protozoan parasites of rodents and their zoonotic significance in Boyer-Ahmad district, Southwestern Iran. Veterinary Medicine International 2016: 2-7. Taylor MA, Coop RL, Wall RL. 2007. Parasites of the Integument. In Veterinary Parasitology www.BlackwellVet.com.

Tijjani M, Majid RA, Abdullahi SA, Unyah NZ. $2020 a$. Detection of rodent-borne parasitic pathogens of wild rats in Serdang, Selangor, Malaysia: A potential threat to human health. Parasites and Wildlife 11(2020): 174-182.

Tijjani M, Majid RA, Abdullahi SA, Unyah NZ. 202ob. Detection of rodent-borne parasitic pathogens of wild rats in Serdang, Selangor, Malaysia: A potential threat to human health. International Journal for Parasitology. Parasites and Wildlife 11(2020): 174-182.

[WHO] World Health Organization. 2019. Zoonotic Disease: Emerging Public Health Threats in the Region 1. World Health Organization. 1-21. 